\title{
EFFECTIVE AND FUNCTIONAL PARTNERSHIP FOR SUCCESSFUL UPSCALING OF TECHNOLOGIES ACROSS AGRICULTURAL VALUE CHAINS, TO FEED AFRICA
}

\author{
Mary Api Igbinnosa \\ TAAT-Clearinghouse (TAAT-CH), International Institute of Tropical Agriculture (IITA), \\ Abomey-Calavi, Cotonou, Benin Republic. \\ Phone: +22996624936; E-mail: apimary66@gmail.com
}

\begin{abstract}
The African continent has a long history of sustainable agricultural development partnerships; all aimed at helping rural poor farmers produce more food for increased income and sustainable livelihood. Yet food insecurity remains endemic, and is expected to worsen as a result of the COVID-19 pandemic. This is happening in the African continent where an estimated $60-75 \%$ of the total population is considered to be in the agricultural food production sector. Known partnership architypes in African agricultural development have only been successful in pilot projects, but have so far failed to achieve the goal of feeding Africa. This paper identifies and categorizes all existing actors in African agriculture into 5 partnership pillars and architypes. Then demonstrates that partnership architype is a critical determining factor in upscaling technologies in African agriculture. It found the Risksharing architype to have the highest $60 \%$ score on the functional partnership indicator index, compared to other architypes studied. Based on findings, this paper proposes a universal and functional partnership model, with contents and principles that will successfully upscale technologies: and that will transform African agricultural development programs, specifically the AfDB TAAT program to feed Africa.
\end{abstract}

Keywords: Technologies, Partnership, Scaling-up, archetype. 


\section{BACKGROUND}

The African continent has a long history of partnerships for sustainable development. One of the first recorded cases dates back to 1953 when a World Bank mission helped the Federal Republic of Nigeria with the groundwork for its post-independence development (Eicher, 2003). Since then, the African development trajectory has been influenced by various developmental approaches and partnerships consisting of financial supporters and technical supporters. Agriculture is one of the important areas of development assistance. Among the partners providing technical and financial support for agricultural development in Africa are, development organizations, technologies custodians, research Institutions (national and international), standard/sanitary organizations, trade institutes, academia, capital markets, commercial banks, development finance institutions, direct foreign investments, risk sharing institutions, private sector, just to name a few. Partnership alignments in various permutations of above partners resulted in fairly distinguishable partnership architypes; all aimed at helping the rural poor to produce more food for sustainable livelihood.

Food insecurity remains endemic to Africa, and is expected to worsen with the COVID-19 pandemic. The agricultural sector has been reported to employ 65 to $70 \%$ of the African population(Lopes, 2013; AfDB, 2016, 2017).Yet, only 10\% Africans living in poverty in the 1970s, has since increased to 70\% in 2010 (Moyo, 2010). The number of people affected by hunger continues to increase (FAO/IFAD/UNICEF/WFP/WHO, 2020). An estimated $70 \%$ of people living in abject poverty and affected by hunger, live on small rural farms; and depend on agriculture for their livelihood (World Bank, 2008).More than half a century later, existing partnership architypes in Africa are yet to enhance farmers' capacity for increased food production (Razanakoto et al., 2018). The call to rethink and restructure African agricultural development business, and value chain, to successfully feed Africa is growing louder: Developing a successful Agricultural partnership alignment and architype remains the critical area of focus. As the ancient Greek physician, Hippocrates said, "Malo nodo, malus quarendus cuneus." "Desperate times call for desperate measures."

\section{LITERATURE REVIEW}

For more than half a century, agricultural development projects in Africa are yet to enhance farmers' performances (Razanakoto et al., 2018). There has been recurrent failure to provide solutions (Witmer, 2018): A phenomenon attributable to treating smallholders as a homogeneous group, together with entrenched interests at the center (Fan et al., 2013; McCalla, 2013). Other problems include too tight scheduling, underestimated costs, bad management and staffing, procurement difficulties, too many components (Ika \& SaintMacary, 2014), and limited finance (UNIDO/CBN/BOI, 2010).Degrees of successes have been recorded with pilot projects, but with attendant cyclical gluts because excess food products fail to reach the markets and households (Otekunrin \& Sawicka, 2019).Effective functional partnership is at the core of any successful aid harmonization and sustainable scaling-up of technologies that will come with measurable improvement on food security (Cooley and Howard, 2019).

Attempts at aid harmonization reveal there are about 63,000 development projects in developing countries, and that a typical developing country is assisted by an average of 30 aid agencies. The consulting business that sprung up around aid delivery in Africa totaled about 
US $\$ 4$ billion per year (Eicher, 2003). Associated consulting business reaching about US \$4 billion per year ensures that there is a steady flow of projects, not minding if farmers' livelihood improves. Consequently, for more than half a century, the steady stream of development projects in Africa have made careers out of aid delivery consulting business but are yet to enhance farmers' performances. There are ample evidences that causes of these failures are attributable to the project masterminds, mostly institutions and funders, who have poor understanding of farmers' predispositions (Razanakoto et al.; 2018). This has led to recurrent failures to provide solutions that are more compatible with context (Witmer, 2018).

Inadequate fixed asset remains critical barriers to microfinance and corporate banking funding to the poor. Even microfinancing of agriculture is yet to reach the majority of these rural poor in developing countries although some authors (Ikechukwu, 2012) are still hopeful. Still in its infancy, financial institutions are becoming innovative to reach the famous smallscale rural producers using inclusive value chain development approaches (Milder, 2008). Unconventional risk-sharing methods like the Nigeria Incentive-Based Risk Sharing System for Agricultural Lending (NIRSAL Plc.), attempt to extend basic financial services to farmers and small and medium enterprises (Latifee, 2008; NIRSAL, 2020). The major thrust here is to stimulate the flow of affordable finance and investments into the agricultural sector and working to mitigate risks along the entire value chain, building long-term capacity, and institutionalizing incentives for agricultural lending. The inherent unstructured nature of individual farmers and small and medium enterprises remains a challenge in innovative financing approaches. This architype is very promising but still new with limited capacity in agricultural sector, limited reach and operational in just few countries in Africa.

Within these contexts, the Technologies for African Agricultural Transformation (TAAT) program is a US\$1 billion innovative and unique partnership strategy designed by the African Development Bank (AfDB)to radically transform African Agriculture into a competitive and inclusive agribusiness sector to achieve food security and increase income for farmers (AfDB, 2016, 2017). This TAAT program is implemented by the International Institute of Tropical Agriculture (IITA) in close collaboration with other centers of the Consultative Group for International Agricultural Research (CGIAR) and specialized institutions such as the African Agricultural Technology Foundation (AATF), the Forum for Agricultural Research in Africa (FARA) and the International Fertilizer Development Center (IFDC) and others (TAAT Clearinghouse, 2019).Collaborators include the World Bank (WB), the Bill and Melinda Gates Foundation (BMGF), the International Fund for Agricultural Development (IFAD), the Alliance for a Green Revolution in Africa (AGRA), and others (Bokanga, 2019).

Although progress has been made to achieve TAAT mandate in the first phase that focuses on 18 agricultural value chains within eight priority intervention areas; there is the need to further strengthen differing per-country-level participation, priorities, synchronization, allocations and integration (Igbinnosa, 2020). This paper proposes an effective functional partnership model that will contribute to strengthen the TAAT program service delivery, and contribute in the push to transform African agriculture in the Feed Africa Initiative. Specific objectives are:

- Identify and categorize existing agricultural partnerships in Africa into architypes. 
- Demonstrate that partnership architype is a critical determining factor in achieving scales in agricultural development.

- Based on evidence, propose principle and strategy for effective partnerships for scale up.

- Propose a functional model for sustainable partnership architype for upscaling technologies for transformation of African agriculture.

\section{METHODOLOGY}

Data was collected for over two years, during several TAAT internal workshops in Kenya and Nigeria; external meetings and engagements in Togo, Congo DRC, Kenya, Burkina Faso, and Benin Rep; and TAAT stakeholders' meetings in Nigeria and Kenya. Other sources of data are, TAAT Compacts Technical Coordination and field trips; TAAT Compacts workplan development, assessment and approval process; regular review of the 15 TAAT Compacts' Quarterly Reports; and personal communications. Specifically;

\subsection{Synergic workshops}

Workshops brought together the Project Steering Committee (PSC), the 15 TAAT Compacts Coordinators, the TAAT Program Management Unit, TAAT Clearinghouse, TAAT program coordinating team at the AfDB, and key stakeholders. These workshops aimed to achieve a common understanding, vet technologies, develop work-plans, create synergies, and fund the nine Commodity Value Chain Compacts and six Enabler Compacts. Also fostered external and internal linkages among multinational and multilateral agencies (AfDB, IFAD, WB).

\subsection{Private Sector involvement}

Mechanisms for private sector participation aimed at efficiency and post-program sustainability. TAAT compacts' identified technologies and engage finance leveraging. Some engaged finance institutions include the One Acre Fund, the Equity Bank (mostly in East Africa), and the Nigeria Incentive-Based Risk-Sharing System for Agricultural Lending (NIRSAL).

\subsection{Field Trips and Questionnaires}

To gauge extent of program implementation, fieldtrips were made to Eastern and Southern Africa and West Africa in 2018. Data collected include technologies for dissemination and upscaling. Partnership template spreadsheets were prepared for all TAAT Compact Coordinators complete. Including from Compacts Quarterly Reports assessment, all data collected were assessed, evaluated, and interpreted as pie charts, bar graphs, tables, and diagrams: using Microsoft Excel and Microsoft Visio. All data presented are the averages of all 15 TAAT Compacts replicates.

\subsection{Functional Partnership Indicator Index}

On a scale of 1-10 percentage score points, each identified architype was assessed for viability, functionality and likelihood to improve African agriculture on a sustainable basis. 


\section{RESULTS AND DISCUSSION}

\subsection{Pillars of Successful Partnership Model}

Existing African agricultural development partnerships architypes identified during the study period are classified into five, namely: The State-focused architype, Institutionfocused architype, Donor-focused architype, Risk-sharing architype, and Technologyfocused architype. Experiential analyses reveal there are 5 pillars required to develop an effective functional partnership architype for scaling-up agriculture. These proposed pillars include Pillar 1, Governance System; Pillar 2, Production system; Pillar 3, Market system; Pillar 4, Credit system; and Pillar 5, Facilitation system (figure 1).

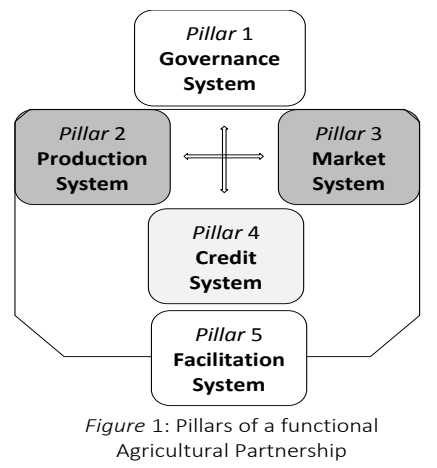

i. Pillar 1, Governance systems: This system controls the environment of the agricultural value chain. Systemic contents include good guiding policies and laws, regulations that impact costs and risks borne by actors, cultural norms, access to resources, rights protection, and coordination; and conflict resolutions. A functional governance system builds on principles of empowerment like easy access to credit, equitable consensus building and prompt action behind good policy action, and noninterference that allows freedom of expression in the core production and marketing systems. Or else, the system will be weak from inconsistent interest-driven policies, and lack of adequate political will and coordination (figures 2 and 3). Katie (2018) agrees that investment incentive, efficient inclusiveness, and good performance indicators, influence the entire system (Katie, 2018).

\begin{tabular}{|c|c|}
\hline $\begin{array}{l}\text { Strength } \\
\text { 1. Donors (sovereign loans and grants) } \\
\text { 2. } 10 \% \text { national budget allocation to agriculture } \\
\text { development. (Maputo Declaration, 2003) } \\
\text { 3. Ownership of programs } \\
\text { 4. NAIP }\end{array}$ & $\begin{array}{l}\text { Weaknesses } \\
\text { 1. Lack of capacity to design and } \\
\text { implement transformation agenda } \\
\text { 2. Exception of few countries, little } \\
\text { political will in support of agriculture } \\
\text { 3. In-country coordination of all } \\
\text { supports to agriculture limited to few } \\
\text { countries }\end{array}$ \\
\hline $\begin{array}{l}\text { Opportunities } \\
\text { 1. Donor initiatives including Feed Africa } \\
\text { 2. Natural and human resources suitable for } \\
\text { agricultural development }\end{array}$ & $\begin{array}{l}\text { Threats } \\
\text { 1. Inconsistent policies } \\
\text { 2. Policies tied to government of the } \\
\text { day }\end{array}$ \\
\hline
\end{tabular}


ii. Pillar 2, Production System: This system consists of all segments of the supply chain that add value to the agricultural products. Content includes talent-driven production and productivity behind innovation and creativity. Other contents are seeds and farm inputs with mechanization, food production agronomy, industrial food processing, and other fixed and non-fixed food production assets. It is estimated here that $85-90 \%$ of the total 65 to $70 \%$ of the African population employed in the agricultural sector, as reported by Lopes (2013) and AfDB (2016), would prefer to be actors in other nonagricultural systems. This observation is however open for further studies. The strength of the proposed system is that it functions optimally by identification of talented farmers in the medium-term that drive creative and innovative production in an enabled environment that allows freedom of expression.

iii. Pillar 3, Market System: This system focuses on strong horizontal and lateral multilevel linkages between food producers and consumers, and between finance providers and consumers. Absorbing excesses, the market system pillar across the agricultural value chain will discourage post-harvest cyclical gluts resulting from inability of producers to market excess supplies that disrupt the supply chain: and assist producers meet the strict sanitary and quality requirements (Hesser, 2019).

iv. Pillar 4, Credit System: This system focuses on the easy-flow of investment credit from financial banks and actors to the agricultural production system. Access to easy credits as loans, grants, subsidies, savings, and gifts to allow talented actors especially farmers freely express themselves. According to Coley and Howard (2019), the unmet demand for smallholder finance is estimated at $\$ 200$ billion.

v. Pillar 5, Facilitation System: The 2003 conference on aid harmonization revealed that there were around 63,000 development projects in developing countries and that the typical developing country is assisted by an average of 30 aid agencies (Eicher, 2003) facilitated by non-governmental organizations (NGOs), research Institutions (national and international), academia, private sector and other implementing partners.

\subsection{Proposed Architype for Successful Technology Upscale}

Identified 5 pillars required to develop an effective functional partnership architype for scaling-up agriculture, with respective contents and principles: form the basis for developing a model architype that guarantees successful technology upscaling to feed Africa (figure 3). 


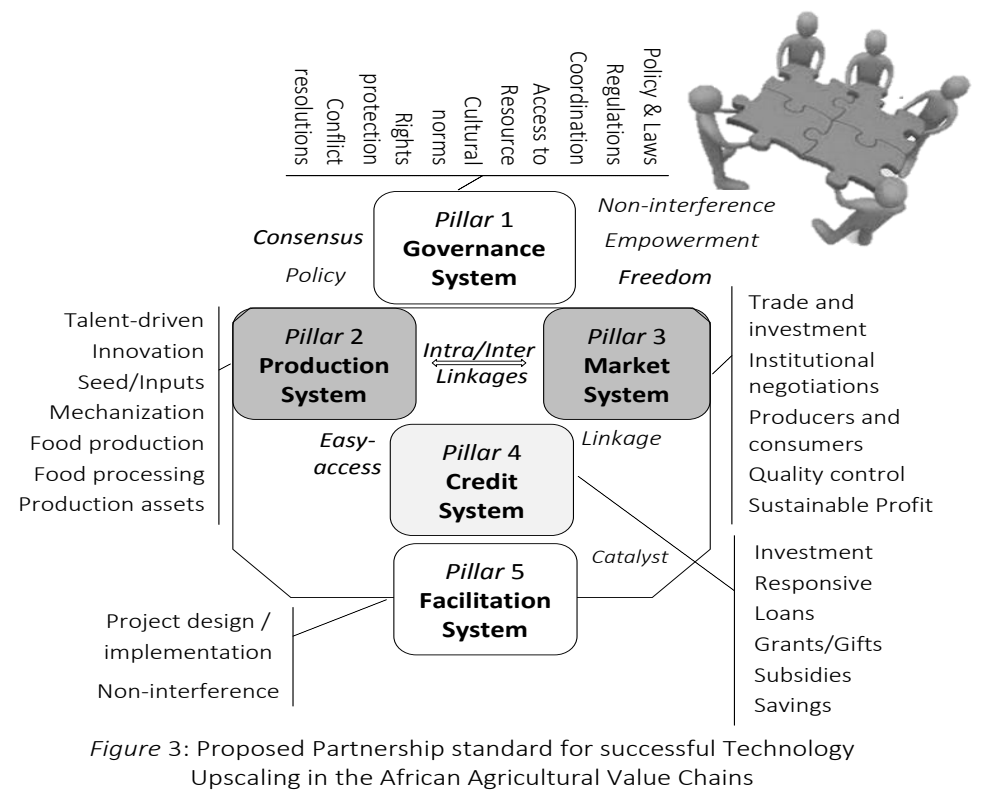

Based on experiential and data evidence, for the first time, major elements of proposed partnership standard for successful technology upscaling to feed Africa include: Policy development based on equitable and non-discriminatory consensus especially at the core production and marketing systems, and non-interfering empowerment that allows agricultural value chain systems operate freely in their decision-making process. Other elements include easy-access to credit, talent and innovation-driven approach, Institutionalization of trade and market negotiations, catalytic intra- and inter linkages (figure 3).

\subsection{Assessment of Existing Architypes}

\section{i. $\quad$ State-focused Architype}

Under this arrangement, state public institutions largely operate the entire agricultural development process, and control the private enterprise actors along the agricultural value chain. The government-owned agro-industrial complexes grow, process, and market export crops products. The production system, together with the market system, play the central role in any successful architype. Scoring only $30 \%$ in the functional partnership indicator index (table 1), the state-run architype largely views farmers as service providers, or simply as farm hands. Widespread corruption in this architype since translated into benefits at the macroeconomic level, with little or no benefits at the level of poor rural farmers especially rural women farmers (Due \& Gladwin. 1991; KonaduAgyemang, 2000; Fan et al., 2013; Kimengsi et al., 2016). Additional weaknesses of this architype include the fact that farm producers along the agricultural value chain lack the freedom to fully express their talents and creativity in food production. Difficult access to agricultural finance further restricts talented farmers and food producers' ability to innovate along the value chain (figure 4, table 1). 


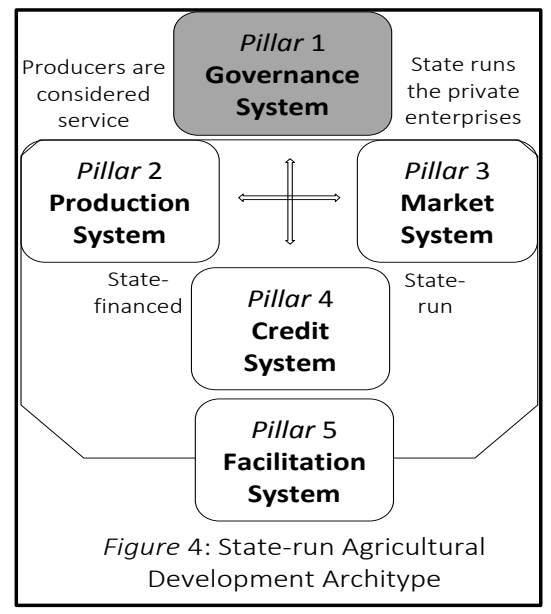

\section{ii. Institution-focused Architype}

Fiercely independent, these are research and development institutions that act largely as facilitators of sustainable development within the African agricultural development. Focused mainly on empowerment and building synergies, funding resources of these institutions are largely from member countries and largely from voluntary donor contributions and grants (FAO, 2017). Therefore, they become responsive to deeply entrenched interests, usually leading to lack of innovation, abundance of fast-track shortlived projects issuing incoherent directives within the African agricultural value chain. It is no wonder that institutional rivalry for control is rife, with limited delivery of credit and of trade and market standards. Scoring only $30 \%$ in the functional partnership indicator index (table 1), deep-rooted interests constrains this architype from addressing known constraints to effective service delivery in the African agriculture.

\begin{tabular}{|c|c|c|c|c|}
\hline \multirow{5}{*}{$\begin{array}{l}\text { Producers } \\
\text { receive } \\
\text { incoherent } \\
\text { direction }\end{array}$} & $\begin{array}{l}\text { Little or no } \\
\text { innovation }\end{array}$ & $\begin{array}{c}\text { Pillar } 1 \\
\text { Governance } \\
\text { System }\end{array}$ & $\begin{array}{c}\text { Sovereign } \\
\text { loans and } \\
\text { grants }\end{array}$ & \multirow{5}{*}{$\begin{array}{l}\text { Inadequate } \\
\text { trade and } \\
\text { market } \\
\text { standards }\end{array}$} \\
\hline & $\begin{array}{c}\text { Pillar } 2 \\
\text { Production } \\
\text { System }\end{array}$ & $\begin{array}{c}\text { Institutional } \\
\text { rivalry } \\
\text { Control }\end{array}$ & $\begin{array}{l}\text { Pillar } 3 \\
\text { Market } \\
\text { System }\end{array}$ & \\
\hline & $\begin{array}{l}\text { Directives } \\
\text { from } \\
\text { different } \\
\text { short-lived } \\
\text { projects }\end{array}$ & $\begin{array}{c}\text { Pillar } 4 \\
\text { Credit } \\
\text { System }\end{array}$ & $\begin{array}{l}\text { Very limited } \\
\text { credit } \\
\text { system }\end{array}$ & \\
\hline & & $\begin{array}{c}\text { Pillar } 5 \\
\text { Facilitation } \\
\text { System }\end{array}$ & & \\
\hline & \multicolumn{3}{|c|}{$\begin{array}{c}\text { Figure 5: Institution-run Agricultural } \\
\text { Development Architype }\end{array}$} & \\
\hline
\end{tabular}


Table 1: Effective and functional partnership indicator index

\begin{tabular}{|c|l|c|c|c|c|c|c|}
\hline S/N & \multicolumn{1}{|c|}{ Elements } & Control & State & Institution & Donor & Risk & Technology \\
\hline 1. & Talent-driven & 1 & 0 & 0 & 0 & 0 & 0 \\
\hline 2. & Innovative* & 1 & 0 & 1 & 0 & 1 & 0 \\
\hline 3. & Consensus policy & 1 & 0 & 0 & 0 & 0 & 1 \\
\hline 4. & Non-interference & 1 & 0 & 0 & 0 & 0 & 1 \\
\hline 5. & Empowerment & 1 & 1 & 1 & 1 & 1 & 1 \\
\hline 6. & Freedom of expression & 1 & 0 & 0 & 0 & 1 & 0 \\
\hline 7. & Synergy & 1 & 1 & 1 & 1 & 1 & 1 \\
\hline 8 & Easy access to credit & 1 & 0 & 0 & 0 & 1 & 0 \\
\hline 9 & Responsive & 1 & 0 & 0 & 0 & 1 & 0 \\
\hline 10 & Trade negotiation & 1 & 1 & 0 & 0 & 0 & 0 \\
\hline Success indicator index & $\mathbf{1 0 / 1 0}$ & $\mathbf{3 / 1 0}$ & $\mathbf{3 / 1 0}$ & $\mathbf{2 / 1 0}$ & $\mathbf{6 / 1 0}$ & $\mathbf{4 / 1 0}$ \\
\hline \multicolumn{2}{l}{ Percentage score } & $\mathbf{1 0 0 \%}$ & $\mathbf{3 0 \%}$ & $\mathbf{3 0 \%}$ & $\mathbf{2 0 \%}$ & $\mathbf{6 0 \%}$ & $\mathbf{4 0 \%}$ \\
\hline
\end{tabular}

*Opportunity to be creative at the level of the producer

This partnership architype usually views farmers within the core production system only as beneficiaries; therefore, do not promote freedom to innovate. Consequently, institutions quickly learn to virtually 'deliver' without necessarily delivering on the broad real push to feed Africa. Focus on donor funding means that projects are designed more for donor interests and timelines, many times with little or no alignment to actual needs of producers or cultural and seasonal chats of farmers. This agrees with findings of FAO (2014) and Ika and Saint-Macary (2014) that agricultural projects within this architype are plagued with enormous design problem such as tight scheduling, underestimated costs, bad management and staffing, procurement difficulties, too many components to name a few.

iii. Donor-focused Architype

Similar to the institutional architype, funding in this architype is solely from donors. Donor-focused architype was found to have highly divergent priorities that are often

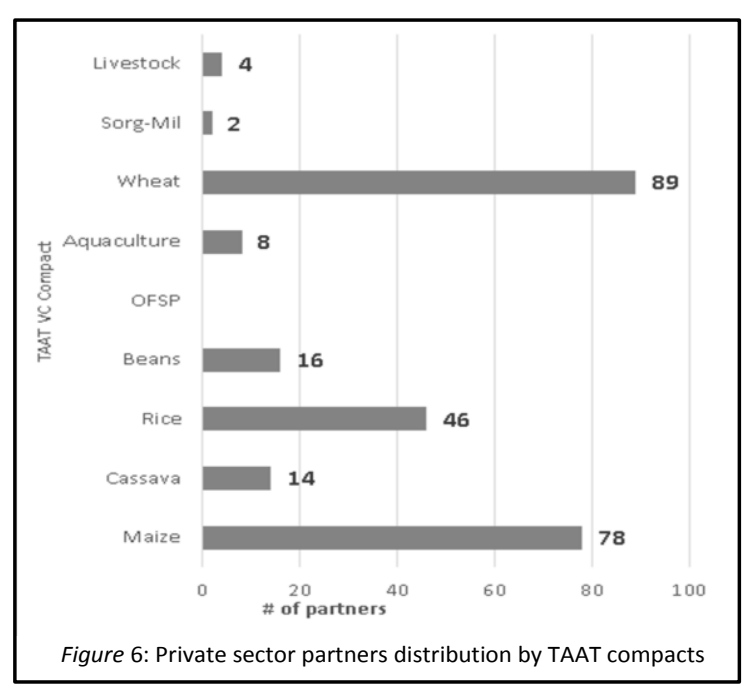
foreign, and may not fully integrate and connect environmental peculiarities to African agriculture. In this architype, macroactors own and control the entire agricultural process. Farmers are only 'service-providers' and do not participate in the decision-making processes: Instead, hand-over their farm harvests as raw materials at low prices beyond the producer's control. This agrees with the findings of Anseeuw \& Ducastel (2012). Although this architype recognizes the ingenuity of the producer system and works 
to put resources directly at their disposal because they cannot provide collaterals that satisfy formal financial systems (UNIDO et al. 2010): but the evidence is that donorfocused architype comes with a list of donor policies, metrics, procedures, and interests that largely shape activities of field actors and implementers. For example, the distribution pattern by private sector partners and actors across TAAT compacts show majority donor-funded projects tend towards cash crops cereals like maize (Zea mays L.), wheat (Triticum aestivum L.), and rice (Oryza sativa L.): Compared to other crops like sweet potato, beans (Phaseolus vulgaris L.), cassava (Manihot esculentum L.), and even livestock and aquaculture (figure 6).In agreement with Fan et al. (2013), shifting more funding to core production and market systems and principles (figure 7), will increase talents and innovation among farmers and producers and increase donor-focused architype functional partnership indicator index, currently at $20 \%$ only (table 1).

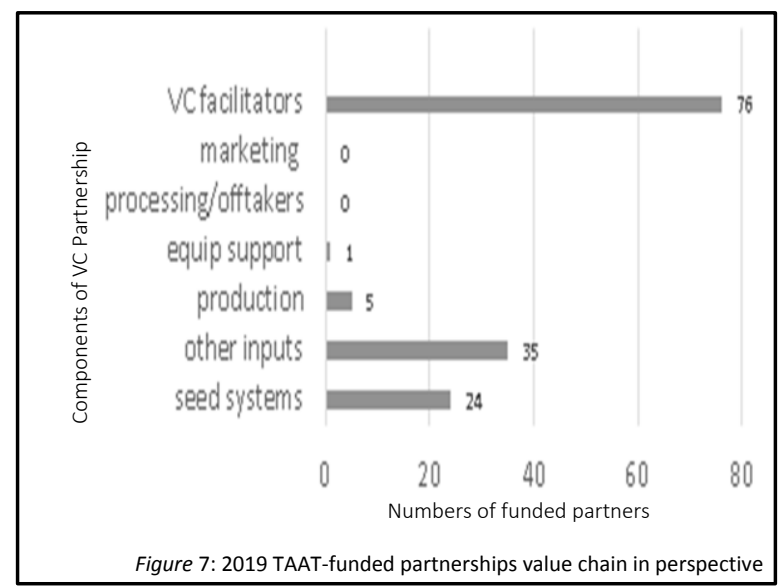

\section{iv. Risk-sharing Architype}

A good example of this architype is the Nigerian Incentive-Based Risk Sharing System for Agricultural Lending (NIRSAL). The highest 60\% score for a functional partnership indicator index was found under this architype, compared to other architypes (table 1). This architype was found to promote innovativeness, empowerment, and a tendency to allow farmers and producers freely produce. It also would build synergy, constant reposition to ease access to credit, and respond to needs of the core production system (figures 1 and 3, table 1). However, this system is not yet talent-driven, and does not build on consensus policy. It is interfering, and its trade negotiation capacity for products farmers and producers to access local and transboundary markets, is still rudimentary (table 1). 


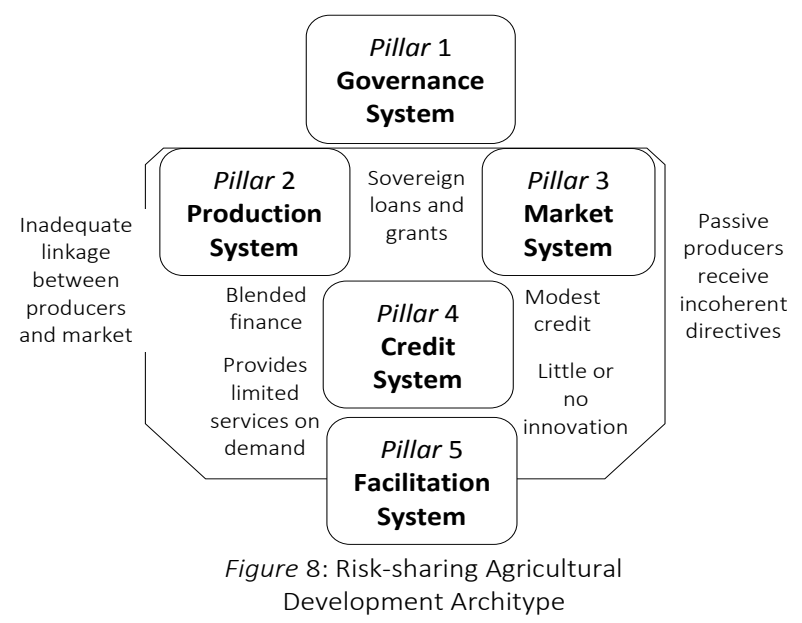

\section{v. Technology Scaling-Up Architype}

A good example of this architype is the AfDB/IITA TAAT.This architype focuses to identify and disseminate proven technologies to boost African agricultural value chain production and productivity.

This architype discourages stand-alone activities, instead would leverage available resources by forging inter-compact collaboration and synergy. Anexampleis the TAAT maize compact that successfully worked with 5 other value chain compacts and all 6 enabler compacts to produce maize grain for the market. For value chain compacts like TAAT rice it was not necessary to forge synergy with other value chain compacts, because rice grains produced was not needed by other value chain compact activities (figure 9). Showing that successfully building synergy and partnerships is driven by common mutually-beneficial need.

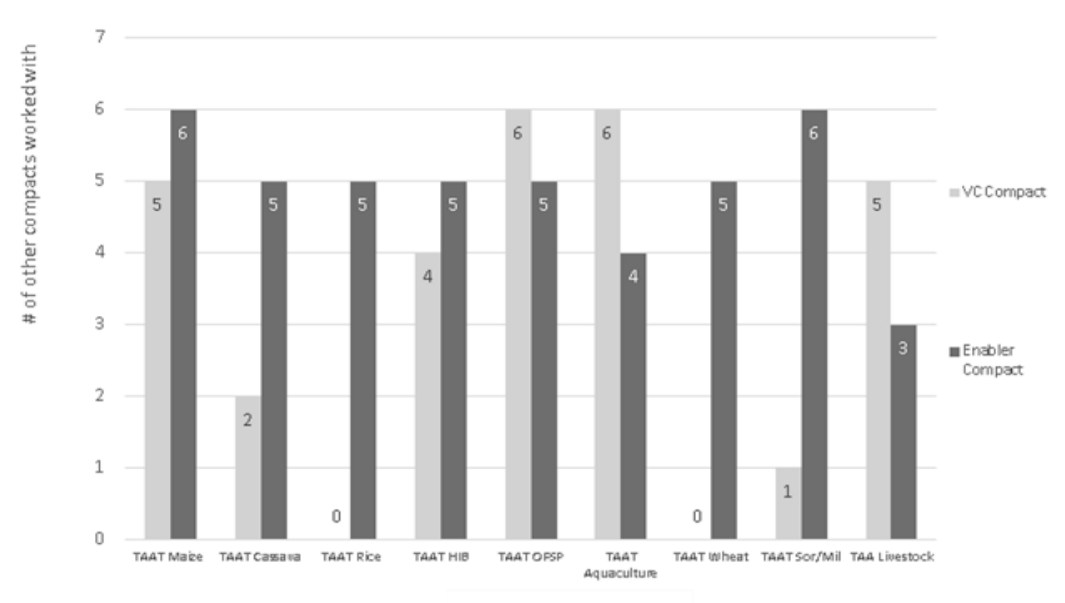

TAAT VC Compact

Figure 9: Partnership inter-compact leveraging and symergy between TAAT value chain compact and enabler compact 
Other specific strengths of this architype include its consensus-based policies and plan of action: however, this happens at the facilitation systemic level not at the production system (figures 1 and 3). With $40 \%$ score in the functional partnership success indicator index (table 1), weaknesses of this architype include absence of responsive innovative, and talent-driven freedom of expression with easy access to credit. Other weaknesses include the lack of systemic trade negotiations capacity to facilitate access of quality food products to local and transboundary markets. According to Otekunrin and Sawicka (2019) and Hessel (2019), this trend will result in observed continuous cyclical gluts of farm products (table 1).

\section{Conclusion}

Like other agricultural programs on the African continent, it is important to remember that the TAAT program is ongoing. Therefore, TAAT is expectedly generating more experiential and developmental data that will continually improve the system. It is to set an enduring framework for systemic improvement that guarantees push to feed Africa that this paper has identified and categorized all existing actors in African agriculture into 5 partnership architypes. Secondly, this paper demonstrates that partnership architype is a critical determining factor in upscaling technologies in African agriculture. Therefore, the risksharing architype was found to have a higher potential for agricultural improvement than other architypes identified. Thirdly, this paper studied and carefully identified contents and principles for effective successful partnerships: and based on these findings proposed a functional model for sustainable partnership architype for upscaling technologies for transformation of African agriculture. Therefore, recommends that partnership standard for successful technology upscaling proposed in this paper be accepted and applied to improve African agricultural development programs, specifically the AfDB TAAT program to feed Africa.

\section{Acknowledgement}

A big thank you goes to Dr Mpoko Bokanga; former Head of the TAAT Clearinghouse for invaluable inputs. I will also like to thank TAAT program Management Unit and all the TAAT compact Coordinators and the host institution - IITA. The author is also grateful to the African Development Bank (AfDB) that provided the grant for the TAAT program and the Bill and Melinda Gates Foundation's support through a grant to IITA toward the project "Support to TAAT Clearinghouse Governance" (INV-002868). 


\section{REFERENCES}

African Development Bank (AfDB). 2017. Technologies for African Agricultural

Transformation: Framework Program in Support of "Feed Africa" Feed Africa: African Development Bank, Abidjan. 26 pp.

African Development Bank (AfDB). 2016. Feed Africa: Strategy for Agricultural

Transformation In Africa 2016-2025. African Development Bank, Abidjan. 30 pp.

Anseeuw W. \& Ducastel A. 2010. New Agricultural Investment Models and Agrarian

Change in South Africa. https://agris.fao.org/agrisearch/search.do?recordID=FR2019128589. Accessed August 2020.

BokangaMpoko (2019). A new paradigm for delivering technology at scale,Annual Appraisal and Assessment (PAR), IITA, Ibadan Nigeria, 23p

Cooley L \&Howard J. 2019. Scale Up Sourcebook. Purdue University Press. 35pp. $1557539049,9781557539045$.

Due JM \& CH Gladwin. 1991. Impacts of structural adjustment programs on African women farmers and female-headed households. American Journal of Agricultural Economics. 1991, Vol. 73, No. 5, pp. 1431-1439

Eicher C. K. 2003. Flashback: Fifty Years of Donor Aid to African Agriculture. 50pp

Fan S, Brzeska J, Keyzer M and Halsema A. 2013. From Subsistence to Profit. Transforming Smallholder Farms. IFPRI. 22pp

FAO, IFAD, UNICEF, WFP and WHO. 2020. The State of Food Security and Nutrition in the World (SOFI). Rome, Italy. 320pp.

Food and Agricultural Organization (FAO) of the United Nations. 2017. Reviewed Strategic Framework. Fortieth Session Conference. 34pp. http://www.fao.org/3/a-ms431reve.pdf

Food and Agricultural Organization of the United Nations (FAO). 2014. Developing sustainable food value chains - Guiding principles. Rome. 89pp

Hesser L. 2019. Against All Odds: Transforming African Agriculture Author House. 242 pp

Hippocrates. 400 BC. Aphorisms. (Translated by Francis Adams). http://classics.mit.edu/Hippocrates/aphorisms.1.i.html

Igbinnosa, Mary Api (2020). Progress Report on Partnerships for the Dissemination of Technologies across Africa. AfDB/IITA TAAT-Clearinghouse Technical Report, Cotonou, Benin Rep. 43p

Ika, Lavagnonand Saint-Macary, Jan. (2014). Special Issue : Why Do Projects Fail in Africa?. Journal of African Business. 15. 151-155. 10.1080/15228916.2014.956635.

Ikechukwu A A. 2012. Microfinance Banking in Nigeria: Problems and Prospects. International Journal of Finance. 1(5): 106-111pp. Accounting Horizon, 2(1), 54 70pp. 
Katie G. 2018. The Enabling Environment in Market Systems Technical Note. https://www.agrilinks.org/post/enabling-environment-market-systems-technical-note . Retrieved September, 2020.

Kimengsi J, Lambi J \&Gwan S. 2016. Reflections on the Role of Plantations in Development: Lessons from the Cameroon Development Corporation (CDC). Sustainability in Environment. 1. 10.22158/se.v1n1p1.

Konadu-Agyemang K. 2000. The best of times and the worst of times: structural adjustment programs and uneven development in Africa: the case of Ghana. The Professional Geographer. 496-483pp

Latifee H I 2008. "The Future of Microfinance: Visioning the Who, What, When, Why, and How of Microfinance Expansion Over the Next 10 Years," Grameen Trust http://www.grameeninfo.org/grameen/gtrust/The\%20Future\%20of\%20Microfinance.pd f.Accessed August, 2020.

Lopes C. 2013. Fifty (50) years of Development Planning in Africa - lessons and challenges. https://www.uneca.org/es-blog/50-years-development-planning-africa-\%E2\%80\%93lessons-and-challenges. Accessed August 2020.

McCalla A. 2013. CGIAR Reform - Why so Difficult? Working Paper No. 14-001. 56pp. Available at SSRN: https://ssrn.com/abstract=2436169 or http://dx.doi.org/10.2139/ssrn.2436169. Accessed August 2020.

Milder B. 2008. Closing the gap: Reaching the missing middle and rural poor through value chain finance. Enterprise Development and Microfinance Enterprise Development and Microfinance. https://www.findevgateway.org/paper/2008/01/closing-gap-reachingmissing-middle-and-rural-poor-through-value-chain-finance.Accessed August 2020.

Moyo D. 2010. Dead Aid: Why Aid Is Not Working and How There Is a Better Way for Africa. 188pp. https://www.amazon.com/Dead-Aid-Working-BetterAfrica/dp/0374532125

NIRSAL. 2020. Enrolment for NIRSAL Agrogeocoop Formation. https://nirsal.com/agrogeocoop/ Accesses August 2020.

Otekunrin, O. \&Sawicka, B. 2019. Cassava, a 21 st Century Staple Crop: How can Nigeria Harness Its Enormous Trade Potentials? 10.13140/RG.2.2.25233.99689.

Razanakoto O, Razafindraibe R, Andriamananjara A, Razafimanantsoa M, Rakotoson T, Smolders E \&Rabeharisoa L. 2018. Failures in agricultural innovation due to poor understanding of farmers' predispositions, Development in Practice, 28:5, 691704, DOI: $10.1080 / 09614524.2018 .1471124$

TAAT Clearinghouse. 2019. Deployment of Combined Technologies to Smallholder Farmers in Kenya. Clearinghouse Technical Report Series 002, Technologies for African Agricultural Transformation, TAAT Clearinghouse Office, Cotonou, Benin. 11 pp. 
UNIDO, CBN \& BOI. 2010. Unleashing Agricultural Development in Nigeria through Value Chain Financing. Working Paper. United Nations Industrial Development Organization (UNIDO), Vienna, Austria. 96pp

Witmer, A. 2018. The influence of development objectives and local context upon international service engineering infrastructure design. International Journal of Technology Management \& Sustainable Development. 17. 135-150. 10.1386/tmsd.17.2.135_1.

World Bank. 2008. World Development Report 2008: Agriculture for Development. Washington, DC., https://elibrary.worldba/doi/abs/10.1596/978-0-8213-6807-7nk.org. Accessed August 2020 